Red Sandstone, but the places where it occurs were not far from the surface of erosion at that time.

In North Wales it can be seen in the Carboniferous Limestone near Llanymynech, in Silurian mudstones on the Denbigh moors, and near Welshpool in Ordovician rocks. In South Pembrokeshire the nearness of the plateau surface to the New Red Sandstone erosion surface is proved by the occurrence in cavities in the Carboniferous Limestone of actual Triassic deposits.

The Forest of Dean is composed of Carboniferous and Old Red Sandstone rocks, but is separated by more than two miles from the nearest outcrop of Trias. The Carboniferous Limestones are in places strongly raddled and important bodies of iron ore occur in them. These are now attributed to the conditions of erosion that prevailed during the New Red Sandstone period. Although the Forest of Dean rises in one place to 1,003 ft. it must be regarded as part of an extensive plateau and it is only in limited areas that it rises above 750 feet. The plateau abuts westward against the great escarpment on the edge of the South Wales Coalfield.

Here again as near Llantrisant the escarpment marks a sharp distinction between the surface of the coalfield to the west and the surface of erosion at its foot.

This part of the great coalfield escarpment is continued into the finest escarpment in the British Isles which is topped by the Brecon Beacons. For anyone who has viewed this magnificent escarpment towering above the ground in front of it, it is impossible to regard seriously the claim now being made that the high ground behind it must be part of the same surface as the much lower ground at its foot.

This lower ground is that which rises gradually to Mynydd Eppynt and thence to the Central Wales plateau.

It is impossible to dissociate the Brecon Beacons escarpment from the escarpments east and south of the Coalfield, nor the plateau at its foot from the plateaux of the Forest of Dean and the Vale of Glamorgan. As these were clearly formed during the New Red Sandstone, they carry with them the implication that the northern escarpment and the plateau associated with it are of the same age and origin. As mentioned above there is independent geological evidence of this in many parts of Wales.

The hypothetical surface devised by Mr. Brown so as to comprise both the Central Wales plateau and the surface of the South Wales Coalfield is clearly a hybrid begotten of the improper association of two physiographic elements which have no essential feature in common. It is as if the present sea floor of Cardigan Bay is regarded as part of the same surface of erosion as the high land which extends back from the cliff top.

Sedgwick Museum,

O. T. JONES. CAMBRIDGE.

19 th November, 1957.

\title{
THE LIMESTONE-SHALE RHYTHM IN THE BRITISH LOWER LIAS
}

SIR,-The letter from Dr. Kent in the last number of the Geological Magazine, in which doubts are expressed about the primary origin of the Blue Lias limestones and shales, can be answered without difficulty. His first point, that many shales in the Midlands are fossiliferous like the limestones, appears to be due to a misunderstanding, partly owing to the brevity of my previous communication. In consequence a little amplification is necessary. The Dorset rocks can, following Dr. Lang, be classified into limestones, marls (grading into marly shales) and paper shales. The first two types are normally indistinguishable in fossil content and differ funda- 
mentally from the generally barren paper shales which, as seen in thin section, are rich in carbonaceous matter arranged parallel to the bedding in fine laminae. The latter are indeed typical "euxinic" deposits. The shales to which Dr. Kent refers are the much more widespread marly shales. Paper shales are developed only at certain horizons and are far less conspicuous. It is reasonable to argue that if a primary origin can be proved in this way for certain beds the same should be assumed for those beds in which the evidence is indecisive.

In dealing with the next matter, viz. the considerable lateral extent of certain limestones, Dr. Kent acknowledges a rhythmic control of the original sedimentation and thus concedes what I regard as the fundamental point at issue. The main dispute then concerns the extent to which $\mathrm{CaCO}_{3}$ might have segregated in the vertical sense, i.e. into bands of limestone, marl, and shale, to accentuate this primary rhythm. In this connection the specimens of Lima gigantea, with their "crazy" structures, prove nothing more than some diagenetic change, a matter already considered in regard to nodule formation. Far more important is the evidence of trace-fossils, such as Chondrites. Both Seilacher (1953) and Scott Simpson (1957) have emphasized that such structures can only be preserved if there is an original difference in the sediments, in this case $\mathrm{CaCO}_{3}$ content. Insofar as subsequent $\mathrm{CaCO}_{3}$ segregation causes any modification of the original patterns it is to obliterate them (this can be proved in the field). It is inconceivable that such delicate structures could be preserved so well if the limestones were formed subsequently in the manner envisaged by Dr. Kent.

It is agreed that unweathered limestones and shales are often not easily distinguishable. This is true not only of boreholes but of fresh sea cliff and quarry sections. Nevertheless the difference is marked enough, as can be proved by chemical analysis. It is dangerous, moreover, to argue that gradual transitions are unlikely to be produced by original sedimentary changes.

Space prohibits fuller consideration of these and related topics, but a detailed account will be published elsewhere.

\section{REFERENCES}

Seilacher, A., 1953. Studien zur Palichnologie. I. Ueber die Methoden der Palichnologie. Neues Jahrbuch Geol. u. Pal., 96, 421-52.

Simpson, S., 1957. On the Trace-Fossil Chondrites. Quart. Journ. Geol. Soc., cxii, $475-496$.

Sedgwick Museum,

A. Hallam.

CAMBRIDGE.

Ist November, 1957.

SIR,--In his letter under this title in the September-October number of the Geological Magazine for 1957, Dr. Kent seeks to dismiss the evidence provided by Chondrites for the deposition of the Lower Lias limestones by normal sedimentation. It is true that one can imagine a mechanism whereby differences of texture in the sediment (such as might exist between the infilling of the Chondrites tunnels and the rest of the bed) are "developed" by differential carbonate segregation during diagenesis. I have proposed this mechanism to account for a type of preservation of Chondrites found in certain Lias nodules. But there is a big difference between this type of preservation and that of the mottled Lias marls and limestones.

And there is another difficulty about Dr. Kent's ideas. He thinks the presence of graded boundaries to the limestones is evidence in favour of their origin by post-depositional segregation. But if the Chondrites structure is essentially a product of such segregation then grading of composition might well be expected within it-and this is not the case. In fact, if the 
varying shades of grey of Chondrites systems which penetrate one another (Simpson, 1 57, p. 492) are to be explained by the varying reaction of slightly different sorts of sediment to calcite segregation, as Dr. Kent requires, then the gradual change from marl to limestone, or vice versa, with which the Chondrites colour changes are associated must also be due to an original difference in the sediment. Thus the lack of sharp boundaries to the limestone beds cannot be evidence of segregation, for it is primary in origin.

Surely the assumption that ordinary sedimentation may not involve graded junctions between limestone and marl is totally unwarranted; and it is difficult even to hold that graded junctions are to be expected with chemical segregation when in fact the concretionary calcareous nodules of the Lower Lias normally show much sharper boundaries than most of the limestones.

So far as I can discover the following summarizes the evidence which supporters of the segregation hypothesis can produce in their favour: (1) occasional fragmented Plagiostoma shells (indicating dilation), (2) thickening of limestone beds around large fossils, and (3) very rare cases in which the attitude of a fossil suggests that limestone surface and bedding surface may not be identical in some places.

I believe (1) and (2) are indeed evidence of segregation, but that such occurrences are confined to a few limestone beds which may be partly concretionary in origin or with which local concretionary centres are associated. The examples of (3) need to be interpreted individually and the evidence they provide at present cannot be claimed to be significant.

\section{REFERENCE}

Simpson, S., 1957. On the Trace-Fossil Chondrites. Quart. Journ. Geol. Soc., cxii, 475-499.

\section{Geology Department,}

S. SIMPSON.

THE UNIVERSITY,

BRISTOL, 8.

6th November, 1957.

\section{ASSOCIATION POUR L'ETUDE GEOLOGIQUE DES ZONES PROFONDES DE L'ECORCE TERRESTRE}

SIR,-A field-meeting of the Association in the Scottish Highlands, in September, 1957, was attended by 19 members, representing the following countries: Belgium 3; France 4; Holland 1; Norway 1; Switzerland 2; United Kingdom 3; U.S.S.R. 4; West Germany 1.

From 13 th -17 th September the party was at Newtonmore, Inverness-shire, under the leadership of Professor J. G. C. Anderson, and studied the structure and high-grade metamorphism of Moinian and Dalradian metasediments and the associated migmatite and pegmatite complexes of Strathspey and Loch Laggan. Opportunity was also taken to see post-tectonic intrusions and glacial features.

The members then travelled via Inverness to Balmacara, Ross-shire, where from 17th-21st September, with Dr. J. Sutton and Dr. G. Wilson as leaders, they saw the Loch Alsh fold, the thrust-slices below the Moine Thrust and the folded Moine and Lewisian near Loch Carron and Loch Duich. Particular attention was paid to the successive sets of small structures, and the relations between these and the large folds and thrusts were demonstrated.

On 21st September the party sailed from Kyle of Lochalsh to Mallaig, thence by train to Fort William where the Ben Nevis Ring Complex was examined; the Parallel Roads of Glen Roy were also visited. After the main part of the excursion concluded on 24th September, some members spent a further few days in Ardnamurchan. 